\title{
Morphological, growth and biochemical features of Dipogon lignosus (L.) Verdc. bean
}

\author{
S. S. Das, M. S. A. Fakir, A. Ferdausi ${ }^{1}$ and M. M. I. Biswas \\ Department of Crop Botany and ${ }^{1}$ Department of Genetics and Plant Breeding, Bangladesh Agricultural University \\ Mymensingh-2202, Bangladesh, E-mail: fakirmsa@yahoo.com
}

\begin{abstract}
Lignosus bean is a perennial vine of Fabaceae. Green seeds, tender leaves and twigs are used as vegetable and dry split cotyledons as pulse soup. Canopy characters, growth and biochemical features of the two genotypes, ' $G 1$ ' and 'G2', of Lignosus bean were studied. Numbers of leaf meter $^{-1}$ vine, \% fertile inflorescence plant ${ }^{-1}$, green pod yield plant $^{-1}$ and dry mass plant ${ }^{-1}$ were greater in $\mathrm{G} 1$ genotype $(10.11,73.17 \%, 3.21 \mathrm{~kg}$ and $2.68 \mathrm{~kg}$, respectively) than G2 genotype $(9.55,66.52 \%, 2.80 \mathrm{~kg}$ and $1.97 \mathrm{~kg}$, respectively). On the other hand, leaflet area, inflorescence length, number of node and pod inflorescence ${ }^{-1}$, fresh pod length and width, hundred fresh seed weight and shell ratio were higher in G2 genotype $\left(33.26 \mathrm{~cm}^{2}, 9.47 \mathrm{~cm}, 24.33,3.51,6.99 \mathrm{~cm}, 1.55 \mathrm{~cm}, 125.08 \mathrm{~g}, 83.61 \%\right.$, respectively) than that in the $\mathrm{G} 1$ one $\left(29.04 \mathrm{~cm}^{2}, 0.61 \mathrm{~cm}, 8.32 \mathrm{~cm}, 16.0,2.52,6.56 \mathrm{~cm}, 1.35 \mathrm{~cm}, 80.57 \mathrm{~g}, 72.69 \%\right.$, respectively). Total soluble solids of seed; and total chlorophyll of leaf and seed were also higher in $\mathrm{G} 2(31.43 \%, 59.19 \mathrm{mg} / \mathrm{l}$ and 0.83 $\mathrm{mg} / \mathrm{l}$, respectively) but Vitamin C of green seed was higher in G1 genotype (43.84 $\mathrm{mg} \%$ ). It may be concluded that the two genotypes can be distinguished on the characters of leaf, flower and seed.
\end{abstract}

Keywords: Canopy character, Genotypes distinction, Dipogon lignosus

\section{Introduction}

Grain legumes are important sources of proteins and dietary fiber in addition to fats, carbohydrates and minerals. They are generally well adapted to a wide range of climates and environmental conditions. Of the thousands known legume species only few have been extensively promoted and used. Many other potential grain legumes are still marginally known. Lignosus bean (Dipogon lignosus (L.) Verdc.) is such an important member of Fabaceae which is reported to be grown as a minor field crop in Asia, Latin America, South America and Australia (Fakir et al., 2008). Lignosus bean is grown mainly for tender leaves and matured green seeds as vegetable, ripe seeds as pulse soup and vines as fodder (Fakir and Hasan, 2009). Although, Purseglove (1988) described Lignosus bean as one of the two botanical varieties of Country bean (Lablab purpureus L. ); but, Lignosus bean is now distinctly different from Country bean (Bari, 2000; Ali, 2009). Country bean is a short-lived, perennial, twining herb with pods being longer and more tapering, and long axis of the seeds in the pod is parallel to the suture (Purseglove, 1988) while Lignosus bean is a long-lived, bushy perennial with pods being shorter and more abruptly truncated, and the long axis of the seeds in the pod is at right angle to the suture (Fakir et al., 2008). Other morphological features are quite similar between Country bean and Lignosus bean.

Country bean is a popular and nutritious vegetable throughout the tropics and subtropics including Bangladesh. There are about 50 species and several hundred variety of Country bean distributed throughout the world (Osama et al., 2002). On the other hand, Lignosus bean is one of the lesser-known legumes of tropics and subtropics and till now only two genotypes of Lignosus bean have recently been identified genetically (Ali, 2009).

Although, some information on morphophysiological aspects, green seed storability, pod growth, floral abscission, seed germination and genetic variability is available in G1 genotype (Bari, 2000; Rahman 2008; Fakir and Hasan, 2009; Fakir et al., 2008, 2009; Islam et al., 2009 and Ali, 2009), there is only one report of comparison of morphological, growth and biochemical features between the two genotypes (G1 and G2) (Das et al., 2012). Therefore, the current research work was carried out to compare the morphological, growth and biochemical characters between $\mathrm{G} 1$ and $\mathrm{G} 2$ genotypes of Lignosus bean. 


\section{Materials and Methods}

The experiment was conducted at the Field Laboratory, Department of Crop Botany, Bangladesh Agricultural University, Mymensingh $\left(24^{\circ} 75^{\prime} \mathrm{N}\right.$ and $\left.90^{\circ} 50^{\prime} \mathrm{E}\right)$, at the elevation of $18 \mathrm{~m}$ above the sea level between May 2008 to February 2009.

Plant materials: Two genotypes of Lignosus bean $(2 n=22)$ viz., one is exotic ('Trinidad', G1') and another is indigenous ('chittagong', G2') were considered. The field experiment was laid out in randomized complete block design with three replications. The seedlings were raised in poly bag with three seeds in each. The seedlings were transplanted at $15^{\text {th }}$ days after sowing (DAS) in the plot of the main field and thinned to one healthy plant/pit between 25 and 30 DAS. The unit plot size was $6.0 \mathrm{~m}^{2}(3 \mathrm{~m} \times 2 \mathrm{~m})$ to accommodate one pit $(50 \mathrm{~cm} \times 50 \mathrm{~cm} \times 50 \mathrm{~cm})$ per plot and one plant per pit. Well decomposed cowdung $(3.20 \mathrm{~kg} / \mathrm{pit})$ and triple super phosphate $(0.06 \mathrm{~kg} / \mathrm{pit})$ were applied as basal dose. Moreover, urea $(0.02$ $\mathrm{kg} / \mathrm{pit})$ and muriate of potash $(0.06 \mathrm{~kg} / \mathrm{pit})$ were also used in three splits as top dress at 20,30 and 40 DAS as the source of nitrogen and potassium, respectively. The blocks and plots were separated by $1.0 \mathrm{~m}$ and $0.5 \mathrm{~m}$ distance respectively. The individual plant was supported by bamboo trellis $(3 \mathrm{~m} \times 2 \mathrm{~m})$. The recommended cultural and management practices were followed (Rashid, 1983).

Sample and data recording: At physiological maturity (PM) of the most pods(changing deep green to light or yellowish green colour), three vines from each replication with one meter $(\mathrm{m})$ length were randomly sampled. Number of nodes and leaves was counted in one meter vine. Number, length and diameter of inflorescence in that vine were recorded. The number of fertile inflorescence per plant, which produced at least one pod was also recorded. Total number of pods (TNP) per plant was estimated by following the method of Fakir et al (1998), as follows: TNP/plant $=$ Number of inflorescence/plant $x$ Number of nodes/inflorescence $x$ Number of pods/node. Total number of potential pods or total number of reproductive units (TRU) was calculated as follows: TRU/plant $=$ No. pods + No. flowers + No. buds + No. scars. Fresh pod yield per inflorescence was estimated by multiplying the number of pods per fertile inflorescence by average fresh pod weight. The summation of pod weight of all the fertile inflorescence in a plant gave pod yields per plant. Leaflet area was recorded from atleast 20 leaves from each replication (Leaf area meter, Model LI-3000, Licor, USA). The plants were harvested at $60-70 \%$ physiological pod maturity and different plant parts were dried in the oven (at $80^{\circ} \mathrm{C} \pm 2$ for 48 hours) and weighed. Total soluble solids (TSS) i.e. both reducing and non-reducing sugar of seeds were recorded using Refractometer (Model No.N-1E, Series 2111-W10, Atago, Japan) at $20^{\circ} \mathrm{C}$ temperature in $\%$ brix unit. Chlorophyll content (total chlorophyll i.e. chlorophyll-a plus chlorophyll-b) of leaf and seed was determined (Yoshida et al., 1976). Vitamin C (Bessey and King, 1933) and Iron (Fe) content (Golterman and Clymo, 1971) of green seed was also determined. The collected data with three replications on various characteristics under study were compiled and analysed statistically to find out the means. Level of significance and t-value was measured by paired samples test.

\section{Results and Discussion}

Morphological features of vegetative and reproductive parts: In one meter $(\mathrm{m})$ vine, there were as many as 10.11 nodes or leaves in $\mathrm{G} 1$ and 9.55 leaves in $\mathrm{G} 2$ genotypes with smaller leaflet area in former $\left(29.04 \mathrm{~cm}^{2}\right)$ than the latter $\left(33.26 \mathrm{~cm}^{2}\right)$ (Fig. 1A). Vine diameter was thicker in $\mathrm{G} 2(0.89 \mathrm{~cm})$ than $\mathrm{G} 1$ one (0.61) (Table 1). G2 genotype produced longer $(9.47 \mathrm{~cm})$ and thicker $(0.75 \mathrm{~cm})$ inflorescence (Fig. 1E) which bore more nodes (24.33) per inflorescence while these were $8.32 \mathrm{~cm}, 0.70 \mathrm{~cm}$ and 16.0, for inflorescence length and diameter, and number of nodes per inflorescence, respectively in G1 genotype. Number of fertile inflorescence per plant was greater (73.17\%) in G1 genotype. The flower is smaller and yellowish in $\mathrm{G} 1$ while it was larger and purple-white in $\mathrm{G} 2$ genotype (Fig. 1B). Number of reproductive unit $(R U)$ per node, per inflorescence and per plant $\left(\times 10^{3}\right)$ was greater in $G 2$ genotype $(3.13,77.23$ and 32.02 , respectively) but number of pod per node was greater in $\mathrm{G} 1$ genotype $(0.20)$ (Table 1$)$. 
Table 1. Some important morphological characters of vegetative and reproductive parts of the two genotypes of Lignosus bean at maturity

\begin{tabular}{|c|c|c|c|c|}
\hline \multirow{2}{*}{ Parameters } & \multicolumn{2}{|c|}{ † Genotype } & \multirow{2}{*}{ t-value } & \multirow{2}{*}{$\begin{array}{l}\text { Level of } \\
\text { sig. }\end{array}$} \\
\hline & G1 & G2 & & \\
\hline \multicolumn{5}{|c|}{ Vegetative parts } \\
\hline Node/ $1 \mathrm{~m}$ vine (No.) & 10.11 & 9.55 & 2.54 & NS \\
\hline Leaf/ $1 \mathrm{~m}$ vine (No.) & 10.11 & 9.55 & 2.54 & NS \\
\hline Vine diameter $(\mathrm{cm})$ & 0.61 & 0.89 & -3.30 & NS \\
\hline Leaflet area $\left(\mathrm{cm}^{2}\right)$ & 29.04 & 33.26 & -1.12 & NS \\
\hline \multicolumn{5}{|c|}{ Reproductive parts } \\
\hline Inflorescence length $(\mathrm{cm})$ & 8.32 & 9.47 & -0.76 & NS \\
\hline \multicolumn{5}{|l|}{ Inflorescence diameter $(\mathrm{cm})$} \\
\hline Top & 0.24 & 0.28 & -3.46 & NS \\
\hline Bottom & 0.70 & 0.75 & -0.46 & NS \\
\hline No. of Inflorescence/plant & 635 & 407 & 12.71 & ** \\
\hline No. of fertile Inflorescence/plant (\%) & 73.17 & 66.52 & 3.19 & NS \\
\hline No. of node /inflorescence & 16.0 & 24.33 & -5.03 & * \\
\hline No. of flower /inflorescence & 6.19 & 6.11 & 0.30 & NS \\
\hline No. of pod /inflorescence & 2.52 & 3.51 & -3.64 & NS \\
\hline No. of bud/node & 2.32 & 2.83 & -2.91 & NS \\
\hline No. of scar/node & 0.26 & 0.14 & 6.92 & * \\
\hline No. of flower/node & 0.45 & 0.28 & 7.36 & * \\
\hline No. of pod/node & 0.20 & 0.14 & 2.26 & NS \\
\hline No. of reproductive unit (RU) /node & 2.78 & 3.13 & -2.16 & NS \\
\hline No. of reproductive unit (RU) /inflorescence & 44.96 & 77.22 & -4.06 & NS \\
\hline No. of reproductive unit $(\mathrm{RU}) /$ plant $\left(\times 10^{3}\right)$ & 28.22 & 32.02 & -34.49 & ** \\
\hline
\end{tabular}

${ }^{\dagger}:$ Results presented are the means of 3 replications. Significance level and $t$-value is determined by paired samples test. ${ }^{*},{ }^{* *}=$ Significant at 5 and $1 \%$ level of probability, respectively; NS=Non significant.

Yield contributing characters: Fresh and dry weights of pods $(3.21$ and $1.60 \mathrm{~kg})$ and dry weight of seeds $(1.10 \mathrm{~kg})$ per plant was higher in $\mathrm{G} 1$ genotype than $\mathrm{G} 2(2.80 \mathrm{~kg}$ and $0.39 \mathrm{~kg}$ for pod fresh and dry weights; and $0.30 \mathrm{~kg}$ for seed dry weight, respectively) (Table 2). Number of pods per plant and seeds per pod were also higher in former (381 and 3.33 for pod and seed, respectively) than in the latter (104 and 3.16 for pod and seed, respectively). Fresh biomass (kg/plant) was greater in G2 genotype (7.49 kg) than G1 $(6.81 \mathrm{~kg})$, but total dry mass (TDM) per plant was higher in G1 $(2.68 \mathrm{~kg})$ than that in the G2 $(1.97$ $\mathrm{kg})$. The size of mature pods of $\mathrm{G} 2$ genotype was larger $(6.99$ and $6.40 \mathrm{~cm}$ long for fresh and dry pods, respectively; and 1.55 and $1.22 \mathrm{~cm}$ width for fresh and dry pods, respectively) than G1 genotype (6.56 and $6.30 \mathrm{~cm}$ long for fresh and dry pods, respectively; and 1.35 and $1.15 \mathrm{~cm}$ width for fresh and dry pods, respectively) (Fig. 1C). One hundred mature fresh pods and seeds of $\mathrm{G} 2$ genotype had greater weight (510.31 g and $125.08 \mathrm{~g}$, for pod and seed, respectively) than $\mathrm{G} 1$ genotype (446.76 $\mathrm{g}$ and $80.57 \mathrm{~g}$, for pod and seed, weights, respectively). This result indicates that pods and seeds are larger in G2 than G1. Dry pods and seeds followed a similar trend. Shelling ratio (seed to pod) was higher in G2 both at fresh (83.61\%) and dry $(78.68 \%)$ conditions than G1 genotype $(71.69 \%$ and $66.95 \%$, respectively), indicating one kilogram of fresh pod of $\mathrm{G} 2$ genotype yields about $836 \mathrm{~g}$ fresh vegetable seeds (Table 2). Seeds are oval, white or mottled with prominent hilum in G1 genotype while they are square, compressed and coffee coloured in G2 (Fig. 1D). 
Table 2. Dry mass production; pod and seed growth characteristics of the two genotypes of Lignosus bean grown at field condition

\begin{tabular}{|c|c|c|c|c|}
\hline \multirow{2}{*}{ Parameters } & \multicolumn{2}{|c|}{ † Genotype } & \multirow{2}{*}{ t-value } & \multirow{2}{*}{ Level of sig. } \\
\hline & G1 & G2 & & \\
\hline Green pod yield/plant (kg) & 3.21 & 2.80 & 1.31 & NS \\
\hline Dry pod wt./plant (kg) & 1.60 & 0.39 & 10.44 & ** \\
\hline Dry seed wt./plant $(\mathrm{kg})$ & 1.10 & 0.30 & 6.44 & * \\
\hline No. of pod/plant & 381 & 104 & 6.11 & * \\
\hline No. of seed/pod & 3.33 & 3.16 & 1.43 & NS \\
\hline Fresh leaflet wt./ plant $(\mathrm{kg})$ & 1.87 & 2.92 & -18.46 & ** \\
\hline Dry leaflet wt./plant $(\mathrm{kg})$ & 0.16 & 0.38 & -8.31 & * \\
\hline Fresh root wt./plant (g) (including nodule) & 219.05 & 326.94 & -7.21 & * \\
\hline Dry root wt./plant (g) (including nodule) & 83.50 & 154.28 & -2.64 & NS \\
\hline Fresh vine (stem + branch) wt/plant (kg) & 1.51 & 1.89 & -9.50 & * \\
\hline Dry vine (stem + branch) wt/plant $(\mathrm{kg})$ & 0.84 & 1.05 & -3.96 & NS \\
\hline Total fresh wt./plant $(\mathrm{kg})$ & 6.81 & 7.49 & -1.40 & NS \\
\hline Total dry mass/plant (TDM) (kg) & 2.68 & 1.97 & 3.07 & NS \\
\hline \multicolumn{5}{|l|}{ Shell ratio $(\%)$} \\
\hline Fresh & 71.69 & 83.61 & -12.62 & ** \\
\hline Dry & 66.95 & 78.68 & -14.26 & ** \\
\hline \multicolumn{5}{|l|}{ Pod length (cm) } \\
\hline Fresh & 6.56 & 6.99 & -1.36 & NS \\
\hline Dry & 6.30 & 6.40 & -0.63 & NS \\
\hline \multicolumn{5}{|l|}{ Pod width $(\mathrm{cm})$} \\
\hline Fresh & 1.35 & 1.55 & -5.14 & * \\
\hline Dry & 1.15 & 1.22 & -1.00 & NS \\
\hline \multicolumn{5}{|l|}{ 100-pod weight (g) } \\
\hline Fresh & 446.76 & 510.31 & -3.90 & NS \\
\hline Dry & 134.20 & 232.04 & -16.24 & ${ }^{*}$ \\
\hline \multicolumn{5}{|l|}{ 100-seed weight $(\mathrm{g})$} \\
\hline Fresh & 80.57 & 125.08 & -35.04 & ** \\
\hline Dry & 38.39 & 60.13 & -10.68 & ** \\
\hline
\end{tabular}

$\dagger$ : Results presented are the means of 3 replications. Significance level and t-value is determined by paired samples test. ${ }^{*},{ }^{* *}=$ Significant at 5 and $1 \%$ level of probability, respectively; NS=Non significant.

Biochemical features: Total soluble solids (TSS) content of seed at PM was higher in G2 $(31.43 \%)$ than G1 $(20.70 \%)$ genotype, but greater amount of TSS was observed in the pericarp of G1 $(9.55 \%)$ than that of G2 (6.55\%) genotype. Total chlorophyll (both a and b) contents in both seed and leaf were higher in G2 morphotype (0.83 and $59.19 \mathrm{mg} / \mathrm{l})$ than $\mathrm{G} 1$ (0.81 and $37.86 \mathrm{mg} / \mathrm{l})$ (Table 3). Iron (Fe) content is more or less similar in the two genotypes but Vitamin-C content of seed was four times higher in $\mathrm{G} 1$ genotype (43.84 $\mathrm{mg} \%$ ) compared to G2 (12.72 $\mathrm{mg} \%$ ) (Table 3).

Table 3. Important biochemical characters of seed and leaf of the two genotypes of Lignosus bean

\begin{tabular}{|c|c|c|c|c|}
\hline \multirow{2}{*}{ Parameters } & \multicolumn{2}{|c|}{ † Genotype } & \multirow{2}{*}{ t-value } & \multirow{2}{*}{ Level of sig. } \\
\hline & G1 & G2 & & \\
\hline \multicolumn{5}{|l|}{ TSS (\% Brix) } \\
\hline Seed & 20.70 & 31.43 & -27.92 & ** \\
\hline Pericarp & 9.55 & 6.55 & 5.35 & * \\
\hline \multicolumn{5}{|l|}{ Chlorophyll content of Seed $(\mathrm{mg} / \mathrm{l})$} \\
\hline Chlorophyll-a & 0.40 & 0.35 & 3.21 & NS \\
\hline Chlorophyll-b & 0.41 & 0.48 & -1.73 & NS \\
\hline \multicolumn{5}{|l|}{ Chlorophyll content of Leaf $(\mathrm{mg} / \mathrm{l})$} \\
\hline Chlorophyll-a & 26.71 & 33.35 & -10.67 & ** \\
\hline Chlorophyll-b & 11.15 & 25.84 & -50.40 & ** \\
\hline Fe-content of Seed $(\mathrm{mg} / \mathrm{kg})$ & 50.23 & 51.34 & -1.75 & NS \\
\hline Vit-C content of fresh Seed (mg \%) & 43.84 & 12.72 & 21.44 & ** \\
\hline
\end{tabular}

$\dagger:$ Results presented are the means of 3 replications. Significance level and $t$-value is determined by paired samples test. ${ }^{*},{ }^{*}=$ Significant at 5 and $1 \%$ level of probability, respectively; NS=Non significant. 
Results of morphological characters revealed that, G2 genotype had bushier and heavier canopy as compared to G1 genotype. But magnitude of reproductive parameters including number of inflorescence per plant, percentage of fertile inflorescence, number of flowers per inflorescence, number of observed pods per plant and green pod yield were higher in G1. In this research work, higher number of fertile inflorescence and greater number of pods per plant in G1 genotype produced higher fresh pod yield (3.21 kg per plant) but in G2 genotype maximum reproductive units per plant resulted in lower fresh pod yield (2.80 kg per plant) due to markedly fewer fertile inflorescence per plant (Table 2). It seems that pod yield is more influenced by the propensity of percentage of fertile inflorescence per plant than by total number of nodes per plant or total number of reproductive units (TRU) per plant (Fakir et al., 2000).

Colour of flower (corolla) was yellowish in G1 genotype but purple-white in G2 (Fig. 1B). Seeds of G1 genotype were rounded, slightly compressed and white or mottled in colour; but in G2 genotype larger, deep coffee coloured seeds were found (Fig. 1D). The results of present investigation on morphological features of vegetative and reproductive parts (Table 1) and pod growth characters (Table 2) of G1 genotype were similar to that of Fakir et al. $(2008,2009)$ and Ali $(2009)$. Further, deep green colour of pericarp turned to light green to light yellow and slight shrinkage of seed from pericarp at physiological maturity indicating visual index of vegetable seed harvest for human consumption (Fig. 1C). Moreover, results of biochemical analysis showed that G2 genotype was better in terms of sweetness (TSS), total chlorophyll and Fe content with considerable amount of Vitamin-C.

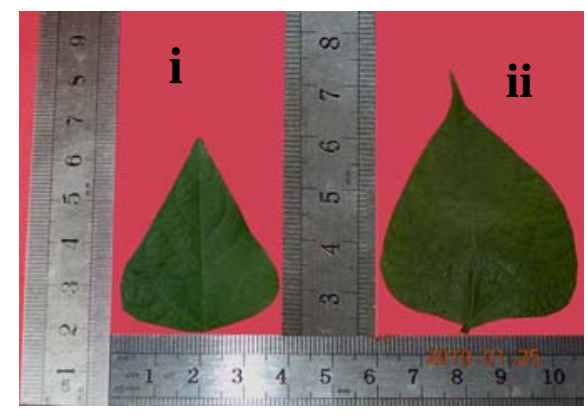

(A)

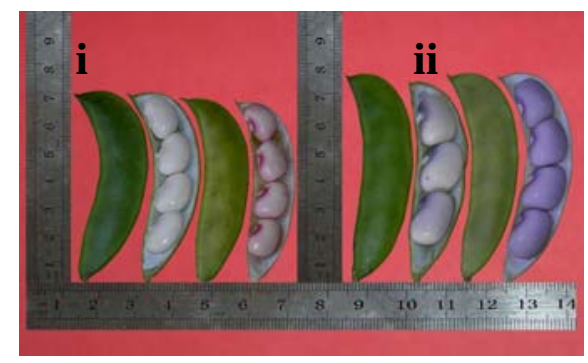

(C)

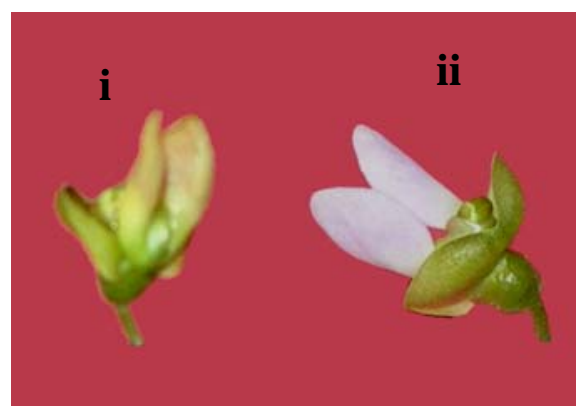

(B)

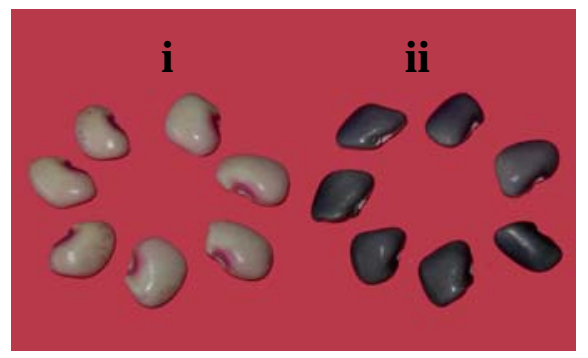

(D)

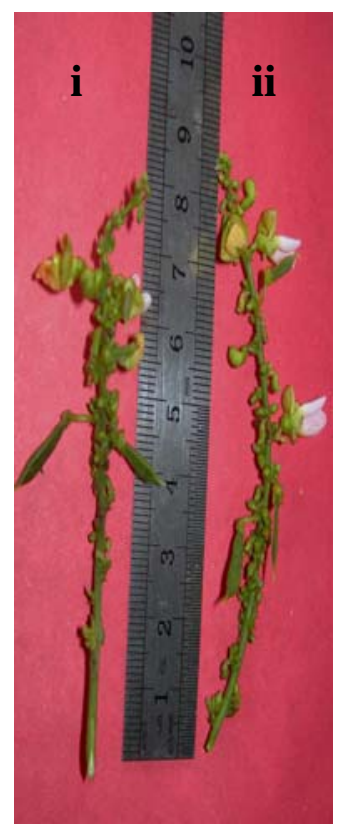

(E)

Fig. 1. Morphological features of a leaflet (A); flower (B); physiological mature pods (C) and seeds (D); and inflorescence with flower and young pods (E) of Lignosus bean (i. G1, and ii. G2 genotypes)

Of the two genotypes of Lignosus bean, G2 genotype can be recognized by deep green larger leaflets, purple-white larger flowers, narrow and sickle shaped larger pods contained coffee coloured compressed seeds; while G1 genotype can be identified by pale green smaller leaflets, yellowish but smaller flowers, obliquely oblong and flattened pods with rounded seeds of white to mottled colour with reddish-pink prominent hilum. 


\section{References}

Ali, A.M. 2009. Pod production and karyotype analysis in Dipogon lignosus (Lignosus bean) and Lablab purpureus (lablab bean). MS Thesis, Dept. Genetics and Plant Breeding, Bangladesh Agric. Univ., Mymensingh, Bangladesh. p. 62-65.

Bari, S.M. 2000. Study of morphological features and flower abscission in Lignosus bean (Dipogon lignosus). MS Thesis, Dept. Crop Bot., Bangladesh Agric. Univ., Mymensingh, Bangladesh. p. 36-45.

Bessey, O.A. and King, C.G. 1933. The distribution of vitamin-C in plant and animal tissues and its determination. J. Biol. Chem., 103: 687 (Methods of vitamin assay. 1966. $3^{\text {rd }}$ Edi. The association of vitamin chemists, Inc. Inter Science Pub., London. p. 294-299.)

Das, S.S., Fakir, M.S.A., Islam, M.J. and Ferdausi, A. 2012. Abst. Souvenir, $3^{\text {rd }}$ Int. Seed Conf. "Quality Seed for Food Security under changing climate", Seed Sci. Soc. Bangladesh, Bangladesh Agric. Univ., p. 25

Fakir, M.S.A. and Hasan, S.M. 2009. Effect of planting date and shading on reproductive character and yield of Lignosus bean (Dipogon lignosus). Bangladesh J. Crop Sci., 20(2): 175-180.

Fakir, M.S.A., Bari, S.M.A. and Prodhan, A.K.M.A. 2008. Morphological features of Dipogon lignosus. Bangladesh J. Crop Sci., 19(1): 231-235.

Fakir, M.S.A., Bari, S.M.A. and Prodhan, A.K.M.A. 2009. Flower production and reproductive abscission in Lignosus bean (Dipogon lignosus). Bangladesh J. Crop Sci., 20(1): 49-54.

Fakir, M.S.A., Hossain, M.A., Hossain, A.K.M.Z., Prodhan, A.K.M.A. and Afsaruzzaman, S.M. 2000. A study of flower production and abscission in country bean (Lablab purpureus). Bangladesh J. Agric. Sci., 28: 310-315.

Fakir, M.S.A., Umaharan, P. and McDavid, C.R.1998. Study of floral abscission in relation to yield in pigeonpea (Cajanus cajan (L.) Millsp.). Proc. $20^{\text {th }}$ Sci. Conf., Bangladesh Assoc. Adv. Sci. Part-2:119-125.

Golterman, H.L. and Clymo, R.S. 1971. Methods of chemical analysis of fresh water. IBP Handbook no. 10. Blackwell Scientific Pub., Oxford and Edenbourgh. p.41-46.

Islam, F., Das, S.S. and Fakir, M.S.A. 2009. Effect of stage of seed maturity on seed germination and seedling growth in Lignosus bean (Dipogon lignosus). Abst. Int. Conf. Quality Seed and Food Security, 17-19 February, 2009, Bangladesh Agric. Univ., Mymensingh. p. 66

Osama, O.A., Abdullahi, H., Abdel Wahab, H. and Abd Elmoneim, O. 2002. Proximate composition, minerals, tannins, in vitro protein digestibility and effect of cooking on protein fractions of hyacinth bean (Dolichos lablab). J. Food Sci., 39: 111-115.

Purseglove, J.W. 1988. Lablab in Tropical crops: Dicotyledon, ELBS edn., Longman, London. p. 273-275.

Rahman, M.H. 2008. Physiochemical changes and storageability of edible Lignosus bean. MS Thesis, Dept. Hort., Bangladesh Agric. Univ., Mymensingh, Bangladesh. p. 31-56.

Rashid, M.M. 1983. Shabjir Chash. $1^{\text {st }}$ Ed. Begum Shahela Rashid. Bangladesh Agric. Res. Inst., Joydebpur, Dhaka, Bangladesh. p. 131-134.

Yoshida, S., Forno, D.A., Cock, J.A. and Gomes, K.A. 1976. Laboratory manual for physiological studies of rice. $3^{\text {rd }}$ ed., IRRI, Los Banos, Philippines. 